\title{
Kelola
}

Jurnal Manajemen Pendidikan

Magister Manajemen Pendidikan

e-ISSN 2549-9661

FKIP Universitas Kristen Satya Wacana

jurnalkelola@gmail.com

Volume: 6, No. 1, Januari-Juni 2019

Halaman: 97-110

\section{Evaluasi Program Pembaca Baru Alkitab (PBA) Lembaga Alkitab Indonesia (LAI) Di Kabupaten Sumba Barat}

\author{
Merry Bendelina Asalaka \\ Universitas Kristen Indonesia \\ merryasalaka@gmail.com \\ Bambang Suteng Sulasmono \\ Universitas Kristen Satya Wacana \\ bambang.sulasmono@staff.uksw.edu \\ J.T. Lobby Loekmono \\ Universitas Kristen Satya Wacana \\ lobby.loekmono@staff.uksw.edu
}

\begin{abstract}
The research aim is to evaluate the implementation of the New Bible Readers (Pembaca Baru Alkitab/ PBA) program by the Indonesia Bible Institute (Lembaga Alkitab Indonesia/ LAI) which is conducted in the West Sumba district. This evaluative research applies the qualitative descriptive method with CIPP as the evaluation model. The research subjects are the Head of Surveyor and Evaluator, Program Manager, Field Head Staff, Regional Coordinator, and Tutor. The data collection is the interview, observation, and documentation study. The data validation was obtained through the method and data source triangulation. Furthermore, the data were analyzed by conducting data reduction, data presentation, and verification. The evaluation result on the Context Components reveals that the PBA LAI program is required by the congregation of churches in West Sumba. The Input Components of PBA LAI program was constructed systematically and directed to answer the needs of the stakeholders and the congregation's literacy state. The programs were supported by competent human resources in accordance with the criteria set and prepared with training, facilities and budget that support the program implementation for one year, and the required procedures and regulations. The Process Component shows that the whole planned programs have been carried out successfully. However, the result shows that the main obstacle in the implementation of the program was the learning process that ran out of the planned schedule. In addition, there was a lack of supervision by the regional coordinator that didn't go as planned. On the Product Component, shows that the PBA LAI program has given a positive impact in accomplishing the goal of the citizens have learned basic literacy (reading, writing, and counting) within the short term goal, as for the long term goal. And as the long term goal, the congregation has learned to take part and improve their role in serving the church. Lastly, based on the results above, the writer would like to give a suggestion to the Program Manager to execute sufficient program developments and improve the program quality for the program sustainability.
\end{abstract}

Keywords: Basic Literacy (Reading, Writing, and Counting), CIPP, Program Evaluation

\section{Article Info}




\section{PENDAHULUAN}

\section{Latar Belakang}

Penduduk buta aksara di Indonesia masih cukup besar, hingga kini Indonesia belum bebas dari buta aksara. Data dari Direktorat Pendidikan Anak Usia Dini dan Pendidikan Masyarakat, Kementerian Pendidikan dan Kebudayaan (Kemendikbud) memperlihatkan hampir jutaan warga Indonesia masih buta aksara. Di tahun 2016 terdapat 2,07\% dari jumlah penduduk Indonesia atau 3,4 juta jiwa yang masih buta aksara. Angka buta aksara berada pada usia 15 - 59 tahun dan $2 / 3$ dari jumlah jiwa buta aksara adalah perempuan. Sebagian besar buta aksara tersebar di 11 provinsi, yakni Papua (28,75\%), NTB $(7,91 \%)$, NTT (5,15\%), Sulawesi Barat (4,57\%), Kalimantan Barat (4,50\%), Sulawesi Selatan $(4,49 \%)$, Bali $(3,57 \%)$, Jawa Timur $(3,47 \%)$, Kalimantan Utara (2,90\%), Sulawesi Tenggara (2,74\%), Jawa Tengah (2,20\%). Sementara 23 Provinsi lainnya sudah berada di bawah standar angka nasional.

Beberapa daerah dengan persentase buta huruf tinggi itu mendapat perhatian khusus dari Kemendikbud. Hal itu diwujudkan melalui Program Pendidikan Keaksaraan berdasarkan Instruksi Presiden RI No. 5 tahun 2006 dan Peraturan Menteri RI No. 35 Tahun 2006, seperti pelaksanaan program Afirmasi Pendidikan Keaksaraan untuk Papua. Program lainnya adalah Gerakan Indonesia Membaca (GIM) dan program Gerakan Pendidikan Pemberdayaan Perempuan Marginal (GP3M).

Selain program-program yang sudah dilaksanakan oleh Kementerian Pendidikan dan Kebudayaan untuk memberantas buta aksara, Lembaga Alkitab Indonesia (LAI) juga telah mengambil peran dalam Pendidikan Keaksaraan melalui program yang diberi nama program Pembaca Baru Alkitab (PBA) Lembaga Alkitab Indonesia. Program PBA LAI memberikan layanan keaksaraan dasar (membaca, menulis, dan berhitung) bagi umat Kristiani dengan berbasis Alkitab, sehingga warga belajar atau warga jemaat tidak hanya dapat membaca tapi juga dapat memahami Alkitab.

Salah satu daerah yang menjadi sasaran dari program PBA LAI adalah kabupaten Sumba Barat. Berdasarkan data Badan Pusat Statistik (BPS) Nusa Tenggara Timur tahun 2015, kabupaten Sumba Barat merupakan kabupaten yang memiliki persentase terbesar angka buta aksara dari 22 Kabupaten di NTT, dengan persentase $16,23 \%$. Kemudian di tahun 2016 presentasinya menurun menjadi $13,52 \%$ dengan berada pada urutan ke dua buta aksara tertinggi setelah Sumba Barat Daya.

Data statistik Kemendikbud telah mencatat sejumlah provinsi dan kabupaten yang memiliki angka buta aksara tinggi, baik menurut persentase maupun jumlah absolut, jumlah umat Kristiani yang buta aksara cukup signifikan, yaitu Provinsi Papua dan Nusa Tenggara Timur. Untuk itulah selama 15 tahun program ini dilaksanakan oleh Lembaga Alkitab Indonesia (LAI) secara rutin sejak tahun 2004 di daerah-daerah 3T (terdepan, terluar, dan tertinggal), atas pertimbangan masih banyak umat Kristiani yang tidak dapat membaca Alkitab karena buta atau gagap aksara.

Secara administratif, kabupaten Sumba Barat terdiri atas 6 kecamatan dengan total luas daratan $732,42 \mathrm{Km}^{2}$ atau $1,56 \%$ dari total luas daratan wilayah Nusa Tenggara Timur. Jumlah penduduk buta aksara di Kabupaten Sumba Barat tahun 2015 adalah 19,76\% dari jumlah penduduk, yaitu 24.092 jiwa dari 121.921 jiwa penduduk Sumba Barat. Usia terbesar adalah penduduk berusia 15 - 59 tahun dengan buta aksara terdapat di kecamatan Loli 3.216 orang dan kecamatan Lamboya 2.448 orang. 
Tabel 1. Buta Aksara Berdasarkan Kecamatan di Kab Sumba Barat Tahun 2015

\begin{tabular}{|c|c|c|c|c|c|c|c|c|c|c|}
\hline \multirow{2}{*}{ No } & \multirow{2}{*}{ Kecamatan } & \multirow{2}{*}{$\begin{array}{l}\text { Jumlah } \\
\text { (Orang) }\end{array}$} & \multicolumn{2}{|c|}{ 15-24 Tahun } & \multicolumn{2}{|c|}{ 25-44 Tahun } & \multicolumn{2}{|c|}{ 45-59 Tahun } & \multicolumn{2}{|c|}{ Jenis Kelamin } \\
\hline & & & $\mathbf{L}$ & $\mathbf{P}$ & $\mathbf{L}$ & $\mathbf{P}$ & $\mathbf{L}$ & $\mathbf{P}$ & $\mathbf{L}$ & $\mathbf{P}$ \\
\hline 1 & Waikabubak & 1.678 & 348 & 429 & 254 & 292 & 148 & 207 & 750 & 928 \\
\hline 2 & Lamboya & 2.448 & 224 & 393 & 365 & 657 & 279 & 530 & 868 & 1.580 \\
\hline 3 & Lamboya Barat & 1.120 & 95 & 165 & 101 & 142 & 224 & 393 & 420 & 700 \\
\hline 4 & Loli & 3.216 & 542 & 634 & 391 & 473 & 542 & 634 & 1.475 & 1.741 \\
\hline 5 & Tana Righu & 1.431 & 191 & 291 & 183 & 284 & 191 & 291 & 565 & 866 \\
\hline \multirow[t]{2}{*}{6} & Wanokaka & 1.923 & 243 & 392 & 248 & 405 & 243 & 392 & 734 & 1.189 \\
\hline & Total & 11.816 & 1.643 & 2.304 & 1.542 & 2.253 & 1.627 & 2.447 & 4.812 & 7.004 \\
\hline
\end{tabular}

Sumber: data BPS Tahun 2015 (sampel usia 15-24 tahun, 25-44 tahun \& 45-59 Tahun)

Melihat besarnya angka buta aksara, Lembaga Alkitab Indonesia hadir melalui suatu program yang disebut Program Pembaca Baru Alkitab (PBA) Lembaga Alkitab Indonesia yang berupaya untuk menjawab kebutuhan masyarakat di Sumba Barat dalam memberantas buta aksara. Selama proses pelaksanaannya, program PBA tentu memiliki kesulitan-kesulitan dan kendala, di antaranya berhubungan dengan masalah hasil pencapaian evaluasi hasil belajar yang tidak sesuai dengan target yang diharapkan, ketidakhadiran baik warga belajar maupun Tutor dalam proses pembelajaran yang berdampak pada keberlanjutan materi pembelajaran.

Ketidakhadiran warga dalam pelaksanaan program juga ditemukan dalam penelitian yang dilakukan oleh Wahyuni, Masyuri \& Badrih (2017) tentang pemberantasan buta aksara terhadap perempuan di Desa Ngenep, Kabupaten Malang. Banyak dari warga belajar yang merasa sungkan untuk hadir dalam penuntasan aksara, sebagai salah satu kendala yang dihadapi. Ketidakhadiran warga belajar menunjukkan bahwa ada kesenjangan yang terjadi pada kinerja guru yang bertanggung jawab dalam memfasilitasi dan mengarahkan warga belajar serta bagaimana secara kreatif membimbing dan memotivasi warga belajar untuk tetap mengikuti proses belajar. Selanjutnya rendahnya kinerja guru sangat dipengaruhi oleh pengawasan dan kontrol Koordinator Wilayah dalam mengunjungi kegiatan-kegiatan yang dilaksanakan di wilayahnya.

Untuk itulah penulis tertarik untuk mengadakan mengevaluasi program Pembaca Baru Alkitab LAI di Sumba Barat. Evaluasi merupakan kegiatan sistematis untuk memperoleh dan menyajikan informasi atau data mengenai objek evaluasi, yang telah dinilai dan dibandingkan dengan indikator evaluasi, serta hasilnya digunakan sebagai pertimbangan dalam pengambilan keputusan. (Wirawan, 2016; Arikunto \& Jabar, 2009). Evaluasi program adalah proses sistematis untuk mengumpulkan, menganalisis dan menetapkan informasi atau data suatu kegiatan, sebagai masukan dalam pengambilan keputusan tentang tindak lanjut dari program yang sedang atau sudah dilaksanakan. (Wirawan, 2016; Arikunto \& Jabar, 2009; Widoyoko, 2017). Sedang tujuan evaluasi program adalah untuk memberikan rekomendasi atau bahan pertimbangan kepada pengambil keputusan agar dapat menentukan keputusan atas program yang dilaksanakan. Manfaatnya adalah adanya keputusan yang tepat sesuai dengan hasil evaluasi, tentang keberlangsungan program yaitu apakah program perlu diteruskan, diperbaiki atau dihentikan. (Wirawan, 2016; Arikunto \& Jabar, 2009; Mulyatiningsih, 2011).

Penelitian ini bertujuan untuk mengevaluasi program PBA LAI di Sumba Barat, berdasarkan aspek konteks, input, proses, dan produk. Model CIPP dipilih karena 
model ini berorientasi pada keputusan (Mahmudi, 2011; Wirawan 2016), sehingga hasil penelitian ini diharapkan dapat memberikan masukan kepada pemimpin atau pengelola program. Selain itu sifatnya yang komprehensif, sistematis dan berkesinambungan membuat model evaluasi ini banyak digunakan untuk meneliti tingkat keefektifan dan ketercapaian obyek yang dievaluasi, terutama dalam bidang pendidikan (Wirawan, 2016). Sesuai dengan hakikat penelitian evaluatif, maka hasil penelitian ini dapat dijadikan masukan bahan pertimbangan untuk mengembangkan program yang sama ditempat lain (Mulyatiningsih, 2011).

Beberapa penelitian yang sejalan dengan penelitian ini antara lain dilakukan oleh; Wahyuni, Masyuri \& Badrih, 2017; Angin \& Putra, 2017; Sulistyo, 2017; dan Wulandari, 2017. Berbagai penelitian ini memberi gambaran bahwa penelitian program keaksaraan dilakukan dengan metode kualitatif deskriptif dan kuantitatif. Metode penelitian menentukan jenis data apa yang akan dijaring, teknik menjaringnya, apakah akan menggunakan metode kuantitatif, metode kualitatif, atau metode campuran kuantitatif dan kualitatif dan instrumen yang akan digunakan untuk menjaring data. Di samping itu, metode penelitian menentukan bagaimana mentabulasi, menganalisis data dan kesimpulan hasil evaluasi (Wirawan, 2016). Selain menggunakan pendekatan kualitatif dan kuantitatif, program kekasaraan juga dapat diteliti dengan penelitian evaluasi. Penelitian evaluasi terhadap program buta aksara membutuhkan desain evaluasi yang berisi model evaluasi dan metode penelitian. Model evaluasi menentukan jenis evaluasi apa saja yang dilakukan dan bagaimana proses melaksanakan evalusi tersebut.

Adapun hasil hasil penelitian di atas antara lain bahwa bahwa peran dari pihak yang terlibat dan mendukung program menentukan keberhasilan program. Hal ini terlihat dari 100 penelitian Angin \& Putra (2017) yang secara khusus melihat kinerja guru dan dukungan pemerintah yang kurang optimal. Selain itu Program Keaksaraan memfokuskan tutor atau guru sebagai pelaksana inti yang bertanggung jawab terhadap kemampuan baca siswa atau warga belajar, sebagaimana tampak dari penelitian Wahyuni, Machtudz, \& Badrih (2017) yang menunjukkan peran penting tutor sebagai pengajar dan pembimbing sehingga perlu dilaksanakan pelatihan dan pembinaan sebelum pelaksanaan proses pembelajaran keaksaraan. Penelitian dari Augustin dan Nugroho (2017) menunjukkan bahwa motivasi, bimbingan dan arahan tutor berpengaruh besar terhadap minat belajar keaksaraan dan melek aksara pada anak jalanan.

Selain melalui pendekatan kualiatatif deskriptif, beberapa penelitian juga melakukan evaluasi terhadap program keaksaraan, seperti yang dilakukan oleh Sulistyo (2017) dan Wulandari (2017). Penelitian Sulistyo mengevaluasi program budaya membaca di Sekolah Dasar dengan model CIPP. Sedang Wulandari (2017) melakukan evaluasi program keaksaraan fungsional dengan s pendekatan kualitatif dan menganalisa data melalui analisa deskriptif, analisa evaluatif serta analisa SWOT untuk mengetahui peluang, ancaman, kekuatan dan kelemahan dari program.

Tampak bahwa penelitian ini berbeda dengan beberapa penelitian terdahulu baik dari segi jenisnya - bukan deskriptif kualitatif namun evaluatif, maupun dari program yang hendak dievaluasi. Jika penelitian Sulistyo (2017) mengevaluasi program budaya membaca di sekolah dasar maka penelitian ini hendak mengevaluasi program PBA LAI di Sumba Barat dengan model CIPP. Model CIPP bersifat komprehensif dibandingkan dengan model-model evaluasi yang lain.

\section{METODE PENELITIAN}

Penelitian evaluatif ini menggunakan pendekatan kualitatif dan bersifat deskriptif. 
Objek penelitiannya adalah program PBA LAI di Sumba Barat. Data dikumpulkan melalui Manejer Program, Staf Pimpinan Lapangan, Pimpinan Surveyor dan Evaluator, serta 3 orang Koordinator Wilayah yang mewakili 5 Korwil lainnya.

Pengumpulan data dilakukan dengan teknik wawancara, observasi dan studi dokumen. Wawancara dilakukan secara sistematik dan mendalam yang melibatkan Manejer Program, Staf Pimpinan Lapangan, dan Koordinator Wilayah. Observasi dilakukan terhadap kelompok-kelompok belajar pasca progaram PBA LAI dan perpustakaan sebagai tidak lanjut program. Studi dokumen dilakukan terhadap dokumen terkait seperti; Mengenal Program PBA LAI, Laporan Bulanan Pimpinan Lapangan, Laporan Evaluasi Hasil Belajar, Laporan Evaluasi Program, Laporan Akhir PBA LAI di Sumba Barat, dan Term Of Reference Program Pemberantasan Buta Aksara di Kabupaten Sumba Barat, NTT.

Teknik validasi data meliputi teknik triangulasi metode dan triangulasi sumber data. Sedang teknik analisa data menggunakan teknik analisa data kualitatif yang mencakup langkah-langlah reduksi data, penyajian data dan penarikan kesimpulan.

\section{HASIL PENELITIAN DAN PEMBAHASAN \\ Hasil Penelitian \\ Evaluasi Konteks}

Hasil wawancara dengan Pimpinan Surveyor dan Evaluator, Manejer Program, dan Pimpinan Lapangan yang dikonfirmasi dengan dokumen "Mengenal Program PBA LAI" serta observasi menunjukkan bahwa program PBA LAI merupakan salah satu bentuk kepedulian LAI dalam membantu gereja mengatasi permasalahan warga jemaat yang buta huruf atau mengalami kesulitan untuk membaca dengan berbasis Alkitab. Setelah mengikuti program ini diharapkan peserta program dapat memiliki keterampilan membaca, menulis dan berhitung, sehingga dapat dipergunakan dalam kehidupan sehari-hari dan selanjutnya dapat mengambil dan meningkatkan perannya dalam pelayanan di gereja.

Kabupaten Sumba Barat dipilih sebagai target pelaksanaan program PBA LAI, karena 1) Jumlah buta aksara tinggi; 2) permintaan gereja-gereja yang ada di Sumba Barat; 3) merupakan daerah dengan mayoritas Kristen dan berada di wilayah 3T (terdepan, terluar dan tertinggal). Berdasarkan hasil wawancara dan didukung dengan observasi, diketahui pula bahwa sasaran program PBA LAI di Sumba Barat adalah laki-laki dan perempuan buta aksara atau gagap aksara yang tidak dalam atau sedang mengikuti pendidikan formal.

\section{Evaluasi Input}

Hasil wawancara dan observasi menunjukkan rencana dan rancangan program disusun setelah melakukan survey pendahuluan untuk menetapkan kebutuhan. Rencana dan jadwal pelaksanaan program PBA LAI di Sumba Barat, secara garis besar termuat dalam dokumen "Mengenal Program PBA LAI" sebagai berikut.

1. Survey Pendahuluan; tahapan ini dimaksudkan untuk mensosialisasikan program PBA LAI kepada gereja induk (sinode) dan gereja jemaat; menjajaki kemungkinan kerja sama dengan pemerintah setempat; memperoleh informasi yang lebih rinci mengenai wilayah dan warga jemaat yang menjadi sasaran program (pendataan bakal calon warga belajar) secara langsung di wilayah yang akan dilayani; dan menjaring ususlan gereja mengenai calon Tutor yang akan terlibat langsung sebagai nara sumber dalam proses belajar mengajar.

2. Persiapan Pelaksanaan Program; berdasarkan data-data yang diperoleh dari survey pendahuluan, kemudian dilakukan verifikasi dan pemantapan data calon peserta program PBA LAI dan calon Tutor. Langkah berikutnya adalah mengadakan pelatihan Tutor tentang kegiatan belajar mengajar dan 
pemahaman materi program PBA LAI. Setelah para calon Tutor mendapatkan pelatihan di kelas, selanjutnya mereka diberi kesempatan untuk mempraktekkan di lapangan kurang lebih satu bulan. Tahapan ini dimaksudkan untuk memperoleh umpan balik sebagai dasar untuk mengadakan perbaikan terhadap kelemahan-kelemahan yang ditemukan selama praktek

3. Pelaksanaan kegiatan belajar mengajar; para Tutor yang telah memperoleh pelatihan, praktek lapangan dan memperoleh umpan balik melalui pertemuan yang dikhususkan untuk itu, sudah siap melaksanakan proses belajar mengajar. Selama melaksanakan program, Pimpinan Program akan melaksanakan supervisi dan pemantauan.

4. Evaluasi; untuk mengetahui sejauh mana program ini telah mencapai tujuan, pada pertengahan program dan akhir program akan dilaksanakan evaluasi, baik lisan maupun tertulis.

5. Tindak lanjut; berdasarkan evaluasi tersebut, maka akan disusun program lanjutan agar program PBA LAI ini benar-benar mencapai tujuan yang diharapkan.

Hasil wawancara juga menunjukkan bahwa SDM yang terlibat dalam program PBA, ditentukan kriterianya oleh LAI, dan kemudian ditentukan personilnya oleh gereja. Melalui observasi dan studi dokumen ditemukan bahwa SDM yang terlibat dalam program PBA LAI di Sumba Barat terdiri atas: a) Manejer Program sebagai penanggungjawab program dan kuasa pengguna anggaran PBA, b) Pimpinan Lapangan dan Staf sebagai penanggungjawab pelaksanaan program PBA di lapangan, c) Kordinator Wilayah berperan untuk memantau pelaksanaan program yang terjadi di wilayahnya serta d) Tutor atau pihak yang diasumsikan sebagai pelaksana utama proses belajar.

Dana yang dialokasikan untuk program PBA LAI bagi 1.000 peserta, 79 kelompok dan 88 personil (terdiri atas 78 orang tutor, 8 koordinator wilayah, 1 pimpinan lapangan, dan 1 staf adminsitrasi) dan berlangsung selama 1 tahun adalah sebesar Rp. 1.295.882.500,-. Dana itu diperuntukkan untuk mendanai (1) Alkitab (bagi warga belajar dan tutor; (2) Bahan Pelajaran, Alat tulis dan Alat Peraga; (3) Biaya Personil (Tutor, Korwil, PinLap, dan Staf); (4) Dokumentasi, Pondok, Administrasi dan Sekretariat; (5) Pelatihan dan Pertemuan Bulanan, Pertemuan wilayah, Pembukaan dan Penutupan, Lomba antar peserta atau kelompok belajar; (6) Evaluasi I dan II; (7) Survei I dan II; (8) Perpustakan di 8 Wilayah. Sumber pendanaan program PBA LAI di Sumba Barat ini diperoleh dari berdasarkan hubungan kerjasama LAI dengan lembaga-lembaga terkait dan juga gereja-gereja pendukung.

Berdasarkan hasil wawancara, observasi dan dokumen tertulis dan gambar, sarana dan prasarana yang mendukung pelaksanaan kegiatan program PBA LAI di Sumba Barat terdiri dari:

1. Kantor program PBA LAI dan ruang pertemuan yang terletak di jalan Bayangkara, kilo meter 2 Waikabubak merupakan gedung yang disediakan oleh gereja Katolik, Paroki Waikabubak, merupakan tempat yang strategis untuk dilaksanakan pertemuan;

2. Tempat dan Waktu Pembelajaran. Tempat/ruang belajar disediakan oleh gereja jemaat setempat. Dari hasil observasi terlihat bahwa ruang belajar dari setiap kelompok berbeda-beda, ada yang memakai ruang gereja, rumah tutor/jemaat, halaman rumah/gereja, kebun atau ladang tempat warga belajar bekerja. Jadwal pelaksanaan proses belajar program PBA LAI dilaksanakan 2-3 kali dalam seminggu (jam dan tempat menyesuaikan kesepakatan Tutor dan warga belajar);

3. ATK ruang kelas, ATK warga belajar dan tutor, Alat Peraga (kartu huruf, kartu kata, kartu suku kata, kartu bergambar, poster huruf dan angka, dll); 
4. Media Pembelajaran: buku seri 1-12 dan buku cerita-cerita sederhana dan bergambar Alkitab yang diterbitkan sendiri oleh LAI;

5. Metode pembelajaran yang digunakan dalam program PBA LAI adalah pendekatan Andragogi dan metode SAS (Struktur Analitik Sintetik). (Zuchdi \& Budiasih, 1997).

\section{Evaluasi Proses}

Menegaskan hasil wawancara, melalui dokumen Term Of Reference Program Pemberantasan Buta Aksara di Kabupaten Sumba Barat, Nusa Tenggara Timur dan hasil observasi ditemukan rekapan kegiatan Pimpinan Lapangan yang menjabarkan tentang kegiatan-kegiatan program PBA LAI di Sumba Barat, yaitu:

1. Pembukaan Program PBA LAI di Aula Delsos Waikabubak, tanggal 3 - 4 Juni 2016. Tujuan kegiatan adalah membuka dan meresmikan program PBA LAI oleh pengurus LAI. Hasil dari pelaksanaan Pembukaan program adalah a) kesepakatan kerja sama antara LAI dan gereja-gereja; b) kesepakatan kerja sama dengan Bupati Sumba Barat; c) kesepakatan kerjasama dengan Tutor dan Korwil;

2. Pertemuan bulanan Tutor dan Korwil; terdapat 8 kali pertemuan secara rutin tiap bulannya dengan pertemuan awal dimulai pada bulan juli 2016 dan berakhir pada bulan Febuari 2017. Tujuan pertemuan bulanan untuk evaluasi kegiatan melalui sharing informasi dan pendapat untuk menemukan solusi demi perbaikan terhadap kendalakendala yang dihadapi selama pelaksanaan kegiatan program PBA LAI;

3. Pelatihan; Pelatihan I pada tanggal 3 Juni 2016 adalah pelatihan persiapan Mengajar Orang Dewasa dan Pengenalan Materi oleh Dr. Hamba Hinda Mbarambanja, M.Th. Pelatihan II tanggal 7 September 2016 adalah Pelatihan tentang Motivasi dan Pengembangan Diri oleh Dr. Sigit Triyono. Pelatihan III tanggal 5 Desember 2016 adalah Pelatihan Perpustakaan oleh Bu Hilda V. Putong, M.P;

4. Proses Belajar; Proses belajar dilaksanakan 2 -3 kali seminggu dengan jumlah warga belajar 10 - 15 orang per kelompok. Satu kelompok dibimbing oleh 1 Tutor dengan durasi 2 - 3 jam pertemuan. Kelompok terdiri dari 79 kelompok belajar dengan 78 Tutor. Proses belajar I dimulai dari bulan Juni - Oktober 2016 dan Proses Belajar II untuk memahami bacaan dilaksanakan dari November 2016 - Maret 2017;

5. Supervisi atau pengawasan; Pimpinan Lapangan memiliki kewajiban untuk mengunjungi kelompok belajar maksimal $2 \mathrm{x}$ setiap kelompok belajar, jika diperlukan bisa lebih dari jumlah maksimal. Dalam pelaksanaannya, supervisi yang dilakukan oleh Pimpinan Lapangan tidak merata di setiap kelompok. Ada yang belum pernah dikunjungi, ada yang lebih dari 2, ada yang hanya sekali;

6. Evaluasi; evaluasi dilakukan oleh Tim Evaluator dari LAI yang terbagi dalam 8 kelompok di 8 wilayah. Terdapat dua kali evaluasi, evaluasi I bertujuan untuk mengetahui kemampuan membaca dan evaluasi II untuk mengetahui kemampuan memahami bacaan. Evaluasi I dilakukan selama kurang lebih 5 hari dari tanggal 26 Oktober 2016 - 31 Oktober 2016. Evaluasi II dilaksanakan selama kurang lebih 5 hari, dari 23 Februari - 28 Februari 2017.

7. Penutupan; dilaksanakan di Aula Hotel Monalisa 29 April 2017. Tujuan dari kegiatan ini untuk menutup program kegiatan dan untuk menyampaikan kesaksian-kesaksian dari warga belajar, Tutor, Korwil dan jemaat yang telah merasakan pengaruh dari program PBA.

Melalui evaluasi program diperoleh gambaran pelaksanaan PBA LAI selama 5 bulan program berjalan, beberapa kegiatan telah dilaksanakan dan berjalan sesuai dengan jadwal. Beberapa kegiatan lainnya, seperti 
proses belajar tidak berjalan sesuai dengan jadwal yang ditentukan, sehingga progres materi pembelajaran selama lima bulan berjalan tidak mencapai kemajuan yang diharapkan. Kemudian pada kunjungan Korwil ke kelompok belajar juga memiliki frekuensi yang rendah. Secara umum, pelaksanaan kegiatan PBA LAI telah berjalan sesuai yang diharapkan dengan yang perlu dibenahi yaitu peningkatan kinerja Tutor dan pengawasan dan kontrol Korwil.

Kendala-kendala yang dihadapi yaitu proses belajar yang tidak sesuai dengan jadwal dan rencana karena ketidakhadiran baik dari warga belajar maupun Tutor itu sendiri. Hal ini menunjukkan bahwa peran Tutor sebagai fasilitator, motivator dan pembimbing yang tidak berjalan sebagaimana mestinya dan sekaligus menunjukkan rendahnya perkunjungan Korwil untuk mengawasi dan mengontrol kelompok belajar. Namun lewat pertemuan bulanan ditemukan solusi agar Tutor dan Korwil memperbaiki kinerja dengan memotivasi warga belajar, menghadirkan suasana belajar yang menyenangkan dan kondusif, menyediakan hal-hal sederhana seperti sirih pinang, snack dan minuman di saat proses pembelajaran. Pimpinan Program pun perlu melakukan perkunjungan secara intensif dan mendalam melalui live in di setiap wilayah.

\section{Evaluasi Produk}

Selain efektif, program PBA juga berdampak. Secara jangka pendek warga belajar dapat membaca, menulis dan berhitung yang digunakannya dalam kehidupan seharihari. Sedang dalam jangka panjang dengan kemampuan yang dimiliki itu, warga belajar dapat meningkatkan pelayanan dan kualitas layanan di gereja atau jemaat yang dilayani.

Harapan dan umpan balik dari pelaksana program diungkapkan lewat hasil wawancara, yaitu 1) harapan program PBA LAI masih terus dilanjutkan karena mengingat masih banyak warga jemaat yang mengalami buta aksara atau gagap aksara; 2) harapan penuh agar gereja atau jemaat setempat dapat melanjutkan program ini dengan mendukung dan menopang kelompok belajar sehingga tetap melangsungkan proses belajar dan atau memberikan kesempatan kepada warga belajar untuk mengambil peran dalam layanan gereja dalam mengasa kemampuan keaksaraan dasarnya; 3) untuk melanjutkan dan mempertahankan program keaksaraan ini, gereja atau pihak yang terlibat harus memiliki komitmen yang kuat dan kerja sama yang saling bersinergi untuk mencapai tujuan.

Selanjutanya bentuk tindak lanjut yang dilakukan adalah pengadaan perpustakaan yang berada di 8 Wilayah di Sumba Barat. Perpustakan ini LAI berkerja sama dengan gereja untuk menyediakan ruang khusus perpustakaan. Selanjutnya fasilitas-fasilitas seperti pengadaan berbagai macam buku, alat dan bahan penunjang perpustakaan disediakan oleh LAI. Pelatihan pengelolaan perpustakan pun diberikan kepada Tutor atau Korwil yang mengelola perpustakaan sebagai sarana untuk mempertahankan keaksaraan dasar warga belajar yang telah lulus dari program PBA LAI.

\section{Pembahasan}

\section{Evaluasi Konteks}

\section{Program Pembaca Baru Alkitab} Indonesia LAI merupakan jawaban atas permasalahan yang dihadapi oleh gereja-gereja di Sumba Barat sebagaimana tampak dari hasil asesmen kebutuhan LAI melalui survey. Hal ini sesuai dengan pendapat Wirawan (2011) bahwa asesmen kebutuhan perlu dilakukan sebelum merencanakan suatu kebijakan, program atau proyek. Asesmen kebutuhan ini sejalan dengan penelitian Andryani \& Suhartono (2017) yang juga melakukan asesmen untuk mengetahui dan memahami kehidupan masyarakat tempat pelaksanaan program.

Latar belakang program PBA LAI adalah karena masih banyak warga jemaat yang belum mampu membaca, khususnya membaca Alkitab, sebagaiman tampak dari ketika Alkitab dibagikan tidak semua warga dapat membaca 
karena memang buta aksara. Latar belakang ini serupa dengan penelitian Wulandari (2017) yang dilatarbelakngi oleh tingginya jumlah buta aksara masyarakat dengan perekonomian menengah ke bawah di Surakarta, dan penelitian Sari, Farid, \& Pratiwi (2017) yang dilatarbelakangi oleh tingginya buta aksara di Batam.

Pemberantasan buta aksara PBA LAI mengajarkan membaca, menulis dan berhitung secara sederhana yang merupakan kemampuan dasar berbahasa. Hal ini sesuai dengan definisi dari Mulyati (2015:6) tentang membaca dan menulis permulaan yang lebih diorientasikan pada kemampuan tingkat dasar, yaitu kemampuan melek huruf yang mana anak-anak dapat mengubah dan melafalkan lambanglambang tertulis menjadi bunyi-bunyi bermakna tanpa diikuti pemahaman terhadap bunyi-bunyi lambang-lambang tersebut.

Tujuan dan manfaat dari program PBA agar warga jemaat dapat menjadi pembacapembaca baru Alkitab artinya warga jemaat dapat membaca Alkitab, sehingga dapat mengambil peran dalam pelayanan di gereja dan dapat dipergunakan dalam kehidupan sehari-hari. Tujuan dan manfaat ini sama dengan penelitian Wahyuni, Machtudz, \& Badrih (2017) bahwa selain membaca, menulis, dan berhitung warga belajar dapat memanfaatkan kemampuannya untuk mengembangkan perekonomian melalui usaha kreatif sesuai dengan potensi desanya. Demikian pula dengan penelitian Andriyani dan Suhartono (2017) yang tujuan penelitiannya adalah untuk memperbaiki taraf kehidupan diri dan keluarganya baik secara sosial maupun ekonomi.

Pada umumnya program keaksaraan didominasi oleh masyarakat dewasa yang kebanyakan pesertanya adalah perempuan dan merupakan masyarakat yang ada di pinggiran atau pelosok daerah. Sasaran PBA program LAI juga demikian, adalah warga jemaat buta aksara atau gagap aksara yang memiliki motivasi, mau belajar dan tidak sedang mengikuti pendidikan formal. Artinya, sasaran dari program PBA LAI tidak ada pembatasan usia, namun program PBA ini didominasi oleh perempuan dan dalam kategori usia dewasa. Sasaran penelitian Andryani dan Suhartono (2017) juga berada pada usia 20 - 60 tahun.

\section{Evaluasi Input}

Perencanaan program PBA LAI menggunakan pendekatan partisipatif dengan melibatkan Pimpinan Gereja-gereja (Gereja Induk dan Jemaat) yang ada di Sumba Barat, termasuk di dalamnya Korwil, Tutor dan warga belajar. Pendekatan partisipatif ini ditemukan juga pada pengelolaan program buta aksara yang diteliti oleh Andryani dan Suhartono (2017).

Kegiatan program PBA LAI disusun secara sistematis dan mendapat kesepakatan, baik dengan gereja-gereja maupun pelaksana program. Program akan diawali dengan kegiatan Pembukaan pada akhir bulan Mei 2016 dan kegiatan Penutupan pada minggu pertama bulan Maret 2017. Jadi program direncanakan berjalan selama 1 tahun dengan proses pembelajaran selama 10 bulan. Hal ini berbeda dengan temuan dalam penelitian oleh Andryani \& Suhartono (2017) dan Angin \& Putra (2017). Program keaksaraan yang diteliti mereka berlangsung selama 6 bulan dengan proses pembelajaran selama 4 bulan. Menurut Zuchdi dan Budiasih (1997:49-53) dan berdasarkan kurikulum Pendidikan Dasar (1994) pembelajaran membaca dan menulis permulaan diajarkan kepada anak-anak kelas I dan II, mulai dari sikap duduk hingga menguasai percakapan dan dialog anak-anak. Jadi pelaksanaan program PBA LAI ditetapkan selama 1 tahun, dengan proses pembelajaran 10 bulan termasuk di dalamnya evaluasi hasil belajar.

SDM yang terlibat di dalam program telah dipersiapkan melalui pelatihan-pelatihan untuk menunjang kegiatan program PBA LAI di Sumba Barat. Hal ini sama dengan temuan 
pada penelitian Wahyuni, Machtudz, \& Badrih (2017), bahwa sebelum dilaksanakan kegiatan KKN-PPM diawali kegiatan pembekalan untuk mengembangkan pengetahuan, keterampilan, dan sikap mahasiswa dalam melaksanakan kegiatan KKN-PPM.

Selain kredibilitas pengelola, pelaksanaan program PBA LAI di Sumba Barat juga ditunjang dengan keuangan yang memadai. Besaran dana yang dialokasikan dalam pelaksanaan program sebesar 1.200.000,-/orang dengan jumlah 1.000 orang warga belajar. Besaran dana tersebut sudah memadai untuk menunjang kegiatan program PBA selama satu tahun berjalan.

Adapun sarana dan prasarana yang dipersiapkan antara lain; Kantor PBA, Ruang Pertemuan, dan Ruang Belajar. Kantor PBA dan Ruang pertemuan berada pada tempat yang strategis karena berada di pusat kota Waikabubak. Ruang belajar disediakan oleh gereja atau jemaat atau berdasarkan kesepakatan Tutor dan warga belajar, walau tidak semua kelompok belajar memiliki ruangan ruangan khusus untuk belajar, Wulandari (2017) menemukan hal yang sama dalam penelitiannya sehingga digunakan rumah Tutor yang letaknya jauh dan terpencil untuk belajar. Dapat dikatakan bahwa pengadaan sarana dan prasarana sebagai input pelaksanaan program PBA di Sumba Barat sudah memadai, di mana materi-materi pembelajaran yang digunakan sesuai dengan standar pemberantasan buta aksara dari Departemen Pendidikan Nasional RI (Mengenal Program PBA LAI, 2015), kelengkapan lain seperti pengadaan ruang kantor dan ruang belajar LAI bekerja sama dengan gereja jemaat setempat.

\section{Evaluasi Proses}

Secara keseluruhan pelaksanaan kegiatan-kegiatan yang ada dalam program PBA LAI sudah terlaksana secara sistematis dan sesuai dengan yang direncanakan, dengan beberapa perubahan dan penyesuaian dalam jadwal pelaksanaan. Pelatihan program PBA
LAI terdiri dari 3 Pelatihan. Pelatihan I merupakan pelatihan untuk mempersiapkan para Tutor dan Korwil dalam melaksanakan peran, tugas dan tanggung jawabnya, yaitu berupa Strategi Pembelajaran Andragogy, penjelasan materi dan buku ajar, dan strategi atau mekanisme pelaksanaan program. Pelatihan I ini sama seperti dengan penelitian yang dilakukan oleh Wahyuni, Machtudz, \& Badrih (2017) bahwa sebelum dilaksanakan kegiatan KKN-PPM dilakukan kegiatan pembekalan untuk mengembangkan pengetahuan, keterampilan, dan sikap mahasiswa dalam melaksanakan kegiatan KKN-PPM.

Kendala yang dihadapi dalam proses belajar adalah tidak terlaksananya proses belajar sesuai dengan jadwal yang telah ditetapkan. Alasan pertama adalah karena ketidakhadiran warga belajar yang disebabkan oleh jarak tempuh yang jauh, warga belajar merasa tidak pantas mengikuti proses belajar karena usia yang lanjut, malu, sakit, sibuk, mengikuti pesta adat dan sebagainya. Rendahnya minat warga belajar dalam mengikuti kegiatan belajar keaksaraan ini juga ditemukan oleh Wahyuni, Machtudz, \& Badrih (2017) dengan alasan sudah lanjut usia, merasa tidak nyaman jika bertemu dengan orang baru yang mengajar, tidak banyak waktu luang karena harus ke ladang, alasan pernah dulu belajar tetapi tetap tidak bisa membaca atau menulis, jarak tempat belajar yang jauh, dan sebagainya. Wulandari (2017) juga menemukan hal yang sama bahwa dalam proses pembelajaran seluruh anggota tidak bisa hadir secara lengkap dengan alasan kegiatan atau kepentingan pribadi, sehingga beberapa di antaranya mengalami ketertinggalan materi. Alasan kedua, Tutor tidak dapat melaksanakan proses belajar karena mempunyai tugas atau tanggung jawab di luar program PBA LAI. Hal ini juga ditemukan dalam penelitian Angin \& Putra (2017), di mana kinerja pengurus belum optimal karena pengurus, Tutor maupun Staf 
memiliki pekerjaan pokok di lembaga formal atau kantor sebagai Pegawai Negeri Sipil (PNS). Demikian juga dengan Sulistyo (2017), yang menemukan bahwa guru tidak konsisten, guru terkadang malas dalam melaksanakan apa yang menjadi tugas dikarenakan banyak tugas dan kegiatan lain.

Kendala lain yang ditemukan dalam proses belajar adalah rendahnya kesadaran Tutor terhadap tugas dan perannya. Peran Tutor sangat penting dalam proses pembelajaran, antara lain sebagai pembimbing, pembina, fasilitator, motivator dan dinamisator kelompok belajar keaksaraan fungsional (Angin \& Putra, 2017). Mengingat keaksaraan fungsional berorientasi pada minat, kebutuhan pengalaman, cita-cita dan ide dari wagar belajar, maka diperlukan Tutor yang kreatif dan inovatif dalam membangkitkan minat belajar warga belajar agar terus bersedia melanjutkan belajar.

Peran Tutor sebagai pembimbing, pembina, fasilitator dan motivator dalam proses belajar program PBA LAI kurang berjalan dengan baik. Terbukti dari rendahnya kehadiran warga belajar. Jika Tutor menjalankan perannya dengan baik, maka ia dapat meminimalkan ketidakhadiran warga belajar. Peran Tutor sebagai pembimbing dan motivator berpengaruh besar terhadap semangat belajar warga belajar, terbukti dari hasil penelitian Agustin \& Nugroho (2017) tentang kemampuan keaksaraan anak jalanan melalui bimbingan sosial. Motivasi yang kuat akan mendorong warga belajar untuk mau berusaha dalam tujuannya dengan sungguhsungguh, bimbingan dan arahan menjadikan warga belajar memahami proses dan tujuan dari pembelajaran.

Untuk mengetahui perkembangan atau pencapaian hasil belajar dilaksanakan evaluasi hasil belajar. Evaluasi hasil belajar PBA LAI dilakukan oleh Tim Khusus dengan melibatkan Korwil sebagai salah satu anggota tim evaluator. Evaluasi hasil belajar ini juga ditemukan dalam penelitian Angin \& Putra (2007) guna mengetahui proses pembelajaran warga belajar yang melibatkan Tutor dan warga belajar sendiri sebagai evaluator (selfevaluator), sedangkan penelitian oleh Sari, Farid, \& Pratiwi (2017) menemukan bahwa Tutor menjadi salah satu evaluator evaluasi hasil belajar.

Jadi mekanisme pelaksanaan program PBA LAI di Sumba Barat telah berjalan secara sistematis dan sesuai dengan rencana. Seluruh kegiatan telah dilaksanakan dengan beberapa perubahan dan penyesuaian jadwal serta membutuhkan perbaikan dan peningkatan pada: (1) kinerja Tutor sebagai fasilitator, motivator dan pembimbing warga belajar dalam proses pembelajaran; (2) kinerja Korwil untuk mengawasi dan mengontrol pelaksanaan program.

\section{Evaluasi Produk}

Berdasarkan Laporan Evaluasi Hasil Belajar diketahui bahwa sebagian besar warga belajar telah dapat membaca, menulis dan berhitung sederhana. Namun, pencapaian evaluasi hasil belajar tidak sesuai dengan target yang ditetapkan. Target pencapaian hasil belajar yang direncanakan adalah $80 \%$, sedangkan hasil pencapaiannya hanya $70,27 \%$. Walaupun demikian, tingkat hasil belajar yang dicapai dari program PBA LAI di Sumba Barat merupakan salah satu pencapaian yang signifikan bila dibandingkan dengan pelaksanaan program PBA LAI di daerahdaerah lain yang hanya mencapai persentase diantara 60-70\% (Hasil Laporan Program PBA LAI, 2017).

Meskipun nilai evaluasi hasil belajar tidak mencapai target, namun porgram PBA LAI memberikan dampak positif. Dampak dari pelaksanaan program juga, tidak hanya dialami oleh warga belajar yang sudah dapat membaca, menulis, dan berhitung dalam kehidupan sehari-hari bahkan mampu mengambil dan meningkatkan perannya dalam pelayanannya di gereja. Manfaat dari program PBA LAI juga 
dirasakan oleh Tutor, Korwil dan Pimpinan Lapangan yang memperoleh pengetahuan dan pengalaman tentang membimbing orang dewasa, strategi pembelajaran yang kreatif dengan menggunakan bahan dan alat peraga, buku-buku yang menarik dan yang utama bagaimana mengelola program PBA agar tetap berjalan sesuai dengan prosedur, ketentuan dan tujuannya;

Hal sama juga ditemukan dari laporan penelitian Agustin \& Nugroho (2017) dan Wahyuni, Machtudz, \& Badrih (2017) pelaksanaan program sudah efektif dan membawa dampak positif bagi warga belajar. Agustin \& Nugroho melihat warga belajar yaitu anak-anak jalanan melalui motivasi dan bimbingan parenting warga belajar dapat membaca dan menulis serta mengaplikasikan dalam kehidupan sahari-hari. Begitu pula dengan Wahyuni, Machtudz, \& Badrih (2017) melalui KKN mahasiswa sebagai Tutor pemberantasan buta aksara dan melatih berbagai keterampilan membawa dampak pada peningkatan taraf hidup warga belajar, yang sebagian besar adalah perempuan. Berbeda dengan laporan yang diberikan oleh Wulandari (2017) proses membaca, menulis bagi warga belajar sudah terlaksana dengan efektif namun belum ada dampak bagi kesejahteraan warga belajar.

Untuk mendukung keberlanjutan proram PBA LAI di Sumba Barat telah didirikan perpustakaan di 8 titik lokasi wilayah. Melalui perpustakaan ini diharapkan warga belajar dapat meningkatkan kemampuan mereka dalam membaca, menulis, dan berhitung sampai dengan tingkat lanjut bahkan mandiri. Keberadaan perpustakaan ini tidak hanya dimanfaatkan oleh warga belajar, tetapi oleh anak-anak dan remaja bahkan seluruh warga jemaat yang ada di wilayah layanan atau di desa untuk menambah pengetahuan mereka. Hal serupa juga disampaikan oleh Wahyuni, Machtudz, \& Badrih (2017) bahwa tindak lanjut dari program literasi dibangunlah 108
Warung Pustaka sebagai tempat untuk membaca (perpustakaan) dan sekaligus tempat berwirausaha. Pendirian Warung Pustaka ini sekaligus sebagai bentuk pemertahanan dan peningkatan kemampuan warga di bidang keaksaraan dan perbaikan ekonomi.

\section{SIMPULAN DAN SARAN}

\section{Simpulan}

Dari hasil penelitian dan pembahasan di atas dapat disimpulkan bahwa:

Dari aspek konteks; Program PBA LAI merupakan program yang dibutuhkan oleh warga jemaat dari gereja-gereja yang ada di Sumba Barat. Kebutuhan dan kondisi yang diidentifikasi di lapangan mendorong perlunya program keaksaran dalam bentuk Program Pembaca Baru Alkitab.

Dari aspek input; Program PBA LAI di Sumba Barat sudah direncanakan secara sistematis dan terarah untuk menjawab kebutuhan dan kondisi di lapangan melalui kegiatan-kegiatan yang ditopang dengan kompetensi SDM yang sesuai dengan kriteria yang ditetapkan dan dipersiapkan melalui pelatihan-pelatihan, sarana dan prasarana yang menunjang pelaksanaan program, dana yang memadai untuk menunjang pelaksanaan program selama 1 tahun, serta prosedur dan aturan yang diperlukan.

Dari aspek proses; kegiatan-kegiatan program yang direncanakan, seluruhnya telah dilaksanakan tanpa ada yang terabaikan. Ada pun kekurangan yang terjadi dalam pelaksanaan kegiatan dan memerlukan perbaikan yaitu pada kegiatan; Monitoring dan Pengawasan; Korwil tidak melaksanakan tugasnya untuk mengawasi dan mengontrol kegiatan belajar di wilayahnya yang berdampak pada pelaksanaan proses belajar. Proses belajar tidak berjalan sesuai dengan rencana dan jadwal yang ditetapkan, sehingga progres pencapaian materi juga tidak sesuai dengan yang ditargetkan. Namun, kemudian dapat diselesaikan dengan baik melalui solusi-solusi 
yang ditemukan dalam pertemuan bulanan para Tutor dan Korwil dan juga melalui perkunjungan Pimpinan Lapangan dan Manager Program yang memantau langsung pelaksanaan program dan bersama-sama dengan warga belajar, Tutor dan Korwil memberikan arahan dan motivasi agar pelaksanaan program dapat berjalan sesuai dengan tujuan yang diharapkan.

Dari aspek produk; hasil belajar warga belajar masih di bawah target pencapaian kelulusan yang ditetapkan LAI. Namun demikian program PBA LAI telah memberikan dampak positif dan mencapai tujuan yaitu warga belajar telah dapat membaca, menulis dan berhitung permulaan sebagai tujuan jangka pendek, dan sebagai tujuan jangka panjang warga belajar telah mengambil dan meningkatkan perannya dalam layanannya di gereja. Tindak lanjut pun sudah dilaksanakan melalui pengadaan perpustakaan di 8 wilayah pelaksanaan program PBA LAI di Sumba Barat.

Saran

Pertama kepada LAI; berdasarkan evaluasi model CIPP program PBA LAI perlu terus dilaksanakan dengan mengingat beberapa pertimbangan dan perbaikan; 1) meningkatkan pengawasan dan kontrol pengelola program secara intensif dan mendalam pada kegiatankegiatan program; 2) penentuan dan pemilihan Tutor dan Korwil lebih diperhatikan, diperlukan pengajar dan pengawas yang kreatif dan berdedikasi terhadap pelaksanaan program; 3) pengadaan ruang belajar yang kondusif dan nyaman; 4) perlu adanya kegiatan-kegiatan tambahan untuk meningkatkan daya tarik dan semangat warga belajar untuk mengikuti proses belajar.

Kedua kepada Gereja; sebagai lembaga yang menerima manfaat dari hasil program, beberapa hal yang perlu dipertimbangkan oleh gereja, meliputi: (a) gereja harus memiliki komunikasi yang baik dan terlibat secara langsung dalam program; (b) gereja harus meningkatkan perannya dalam program sehingga dapat menjalankan lanjutan program.

Ketiga kepada Pemerintah; rekomendasi yang diberikan kepada pemerintah daerah Sumba Barat meliputi, (a) harapannya Pemerintah Kabupaten Sumba Barat mengambil peran atau terlibat langsung dalam pelaksanaan program keaksaraan; (b) Pemerintah Kabupaten Sumba Barat dapat memperhatikan program-program keaksaraan yang berlangsung di daerahnya, baik pelaksanaan dan program lanjutannya sehingga dapat melakukan evaluasi secara keseluruhan untuk meningkatkan jumlah angka melek aksara dan minat masyarakat terhadap pendidikan.

\section{DAFTAR PUSTAKA}

Agustin, M., \& Nugroho, R. (2017). Kemampuan Keaksaraan Anak Jalanan Melalui Bimbingan Sosial di Unit Pelaksana Teknis Dinas (UPTD) Kampung Anak Negeri Surabaya. EJournal UNESA, 1, 0-10.

Andriyani, D., \& Suhartono. (2017). Pengelolaan Program Pemberantasan Buta Aksara Bertema Keterampilan di Desa Bojong Renged, Kecamatan Teluknaga, Kabupaten Tangerang. SENADIMAS, 2017.

Angin, R., \& Putra, P.M. (2017). Pengelolaan Program Keaksaraan Fungsional di Kabupaten Jember. Jurnal POLITICO Fisipol, 16, 1-16.

Arikunto, S., \& Jabar, C.S.A. (2009). Evaluasi Program Pendidikan: Pedoman Teoritis Praktis Bagi Praktisi Pendidikan. Jakarta: Bumi Aksara.

Badan Pusat Statistik Sumba Barat. (2016). Buta Aksara Berdasarkan Kecamatan di Kabupaten Sumba Barat Tahun 2015. Waikabubak, NTT, 7 Maret 
Lembaga Alkitab Indonesia. (2015). Mengenal PBA LAI. Jakarta: LAI.

—. (2018). PBA Sumba Barat 2017. 5 Maret. http://www.alkitab.or.id/campaigns/pba -sumba-barat-2017/.

Mahmudi, I. (2011). CIPP: Suatu Model Evaluasi Program Pendidikan. Jurnal At-Ta'dib, 6.

Mulyati, Y. (2015). Ketrampilan Berbahasa Indonesia SD. Jakarta: Universitas Terbuka.

Mulyatiningsih, E. (2011). Metode Penelitian Terapan Bidang Pendidikan. Bandung: Alfabeta.

Sari, M.E.P., Farid, Y., \& Pratiwi, D.A. (2017). Strategi Pemerintah Kota Batam dalam Implementasi Program Pemberantasan Buta Aksara di Daerah Hinterland. Dimensi, 6, 63-76.

Sulistyo, A. (2017). Evaluasi Program Budaya Membaca di Sekolah Dasar Negeri. Kelola: Jurnal Manajemen Pendidikan, Vol 4 (1), 48-58.

Wahyuni, S., Machfudz, M., \& Badrih, M. (2017). Pemberdayaan Masyarakat Perempuan Melalui Pemberantasan 'Buta Aksara` Guna
Menumbuhkembangkan Usaha Kreatif Berbasis Literasi dan Potensi Lokal. Jurnal Inovasi Pendidikan, 1, 48-71.

Widoyoko, S.E.P. (2017). Evaluasi Program Pembelajaran: Panduan Praktis Bagi Pendidik dan Calon Pendidik. Yogyakarta: Pustaka Pelajar.

Wirawan. (2016). Evaluasi: Teori, Model, Metodologi, Standar, Aplikasi dan Profesi 'Contoh Aplikasi Evaluasi Program: Pengembangan Sumber Daya Manusia, Kurikulum, Perpustakaan, Buku Teks, Manajemen Berbasis Sekolah, Kartu Indonesia Pintar, Kartu Indonesia Sejahtera, Kartu Indonesia Sehat dan Program Dana Desa. Jakarta: Rajawali Pers.

Wulandari, R. (2017). Pemberdayaan Aksara Masyarakat Pedesaan: Evaluasi Program Keaksaraan Fungsional pada Kelompok "Ngudi Kawruh" di Kelurahan Pasar Kliwon Kota Surakarta. Jurnal Studi Keislaman, 3,110.

Zuchdi, D., \& Budiasih. (1997). Pendidikan Bahasa Indonesia di Kelas Rendah. Jakarta: Departemen P \& K. 